Revue bibliographique pour le domaine irano-aryen

\title{
Hamid Fahimi. An Iron Age Fortress in Central Iran: Archaeological Investigations in Shamshirgah, Qom, 2005. Preliminary Report
}

\section{Rémy Boucharlat}

\section{(2) OpenEdition \\ 1 Journals}

\section{Édition électronique}

URL : http://journals.openedition.org/abstractairanica/40255

DOI : 10.4000/abstractairanica.40255

ISSN : 1961-960X

Éditeur :

CNRS (UMR 7528 Mondes iraniens et indiens), Éditions de l'IFRI

\section{Édition imprimée}

Date de publication : 1 décembre 2013

ISSN : 0240-8910

Référence électronique

Rémy Boucharlat, " Hamid Fahimi. An Iron Age Fortress in Central Iran: Archaeological Investigations in Shamshirgah, Qom, 2005. Preliminary Report », Abstracta Iranica [En ligne], Volume 32-33 | 2013, document 64, mis en ligne le 01 juillet 2016, consulté le 26 septembre 2020. URL : http:// journals.openedition.org/abstractairanica/40255; DOI : https://doi.org/10.4000/abstractairanica 40255

Ce document a été généré automatiquement le 26 septembre 2020.

Tous droits réservés 


\title{
Hamid Fahimi. An Iron Age Fortress in Central Iran: Archaeological Investigations in Shamshirgah, Qom, 2005. Preliminary Report
}

\author{
Rémy Boucharlat
}

\section{RÉFÉRENCE}

Hamid Fahimi. « An Iron Age Fortress in Central Iran: Archaeological Investigations in Shamshirgah, Qom, 2005. Preliminary Report ", in : P. Matthiae, F. Pinnock, L. Nigro, N. Marchetti, eds., Proceedings of the 6th International Congress of the Archaeology of the Ancient Near East, 5 May-10 May 2009 «Sapienza »- Università di Roma. Vol. 2, Wiesbaden, Harrassowitz, 2010, p. 165-183, 15 fig.

1 Les données archéologiques sur l'occupation ancienne du Plateau central étaient très pauvres jusqu'à une date récente, sauf dans la région de Téhéran, principalement des cimetières, ainsi que Sialk, près de Kāšān. Les prospections et sondages de jeunes archéologues des deux dernières décennies sont en train de changer la situation. Ici, il s'agit d'une première recherche sur un site fortifié, sur la bordure méridionale du Dašte Kavīr, à 20 km au sud de Qom. Il est daté de l'âge du Fer II (1200-800 av. n. è.) sur la base du matériel, la céramique grise de cette époque. 


\section{AUTEURS}

RÉMY BOUCHARLAT

CNRS, Lyon 